\title{
Accumulation of low-molecular-weight organic acids in roots and leaf segments of Zea mays plants treated with cadmium and copper
}

\author{
Sławomir Dresler • Agnieszka Hanaka • \\ Wiesław Bednarek · Waldemar Maksymiec
}

Received: 26 September 2013/Revised: 19 February 2014/ Accepted: 3 April 2014/Published online: 27 April 2014

(C) The Author(s) 2014. This article is published with open access at Springerlink.com

\begin{abstract}
Maize seedlings grown in a nutrient solution were treated with $\mathrm{Cd}(50,100 \mu \mathrm{M})$ or $\mathrm{Cu}(50,100 \mu \mathrm{M})$. Roots and separated leaf sections (from the youngestbasal, through the middle-mature, to the oldest-apical) were analysed. Shoot and root fresh weight, and root net growth rates were reduced significantly after $\mathrm{Cu}$ application in comparison to Cd. Copper $(50,100 \mu \mathrm{M})$ and cadmium $(100 \mu \mathrm{M})$ decreased the sum of chlorophyll and total carotenoid pools mostly in mature and old leaf sections. The concentration of $\mathrm{Cu}$ and $\mathrm{Cd}$ increased in the old and mature leaf sections. Analysis of organic acids showed that both metals differently influenced the lowmolecular-weight organic acids (LMWOAs) content in maize leaf sections. In mature sections, the excess $\mathrm{Cu}$ increased the succinate and tartrate contents, whereas in the young ones mainly the tartrate level was elevated. Cadmium elevated citrate accumulation in mature and old sections, compared to the control plants. Malate, the main LMWOA in maize leaves, increased only after addition of $100 \mu \mathrm{M}$ of $\mathrm{Cd}$ (mature and old sections) or $50 \mu \mathrm{M}$ of $\mathrm{Cu}$ (old sections). Analysis of LMWOAs in roots showed that
\end{abstract}

Communicated by J. Kovacik.

S. Dresler $(\bowtie) \cdot$ A. Hanaka · W. Maksymiec

Department of Plant Physiology, Maria Curie Skłodowska

University, Akademicka 19, 20-033 Lublin, Poland

e-mail: slawomir.dresler@poczta.umcs.lublin.pl

W. Bednarek

Department of Agricultural and Environmental Chemistry,

University of Life Sciences in Lublin, Akademicka 15 ,

20-950 Lublin, Poland

W. Maksymiec

Institute of Agrophysics, Polish Academy of Sciences,

Doświadczalna 4, 20-290 Lublin, Poland the excess of $\mathrm{Cd}$ or $\mathrm{Cu}$ induced higher accumulation of tartrate and malate and, additionally, copper increased the citrate content.

Keywords Heavy metals - Maize - Organic acids · Malondialdehyde $\cdot$ Capillary electrophoresis

$\begin{array}{ll}\text { Abbreviations } \\ \text { AA } & \text { Ascorbate } \\ \text { ANOVA } & \text { Analysis of variance } \\ \text { CTAB } & \text { Cetyltrimethylammonium bromide } \\ \text { FW } & \text { Fresh weight } \\ \text { GSH } & \text { Glutathione } \\ \text { HM } & \text { Heavy metal } \\ \text { LMWOA } & \text { Low molecular weight organic acid } \\ \text { LSD } & \text { Least significance difference } \\ \text { MDA } & \text { Malondialdehyde } \\ \text { NGR } & \text { Net growth rates } \\ \text { PC } & \text { Phytochelatin } \\ \text { PCA } & \text { Principal component analysis } \\ \text { PDC } & \text { 2,6-Pyridinedicarboxylic acid } \\ \text { REL } & \text { Relative electrolyte leakage } \\ \text { ROS } & \text { Reactive oxygen species } \\ \text { TBA } & \text { 2-Thiobarbituric acid } \\ \text { TCA } & \text { Trichloroacetic acid }\end{array}$

Introduction

Although some of the heavy metals (HMs) such as iron, zinc, or copper are essential for normal growth, their presence at excess concentrations in soil becomes toxic to plants. These trace elements as well as non-essential HMs 
such as lead or cadmium induce several mechanisms of plant adaptation to HMs stress. One effective way of HM stress reduction is the mechanism of extracellular HM detoxification by reducing the concentration of HMs entering the cell. On the other hand, when HMs enter the cytosol, intercellular mechanisms are involved in detoxification thereof. In such a situation, detoxification of HMs including an efflux of $\mathrm{HMs}$ from root cells due to $\mathrm{H}^{+}$coupled antiport activity (Burzyński et al. 2005), metal transport, chelation, and sequestration into vacuole was observed (Rauser 1999; Sanitá di Toppi and Gabbrielli 1999). Low-molecular-weight organic acids (LMWOAs) participate in both strategies of HMs detoxification: firstly, as plant exudates, organic acids increase extracellular precipitation of HMs by the chelation oxidation-reduction reaction in the rhizosphere; secondly, likewise phytochelatins (PCs) and amino acids, LMWOAs chelate and sequestrate HMs in the vacuole (Rauser 1999; Ma 2000; Ryan et al. 2001).

Previous papers indicate that LMWOAs such as malate, citrate, and oxalate can form a metal-organic acid complex in the vacuole (reviewed in Rauser 1999; Clemens 2001). This mode of detoxification was evidenced at the excess of Al (Ma 2000), Zn (Thurman and Rankin 1982; Harmens et al. 1994), and Ni (Lee et al. 1978; Yang et al. 1997) in nutrient medium.

Although the role of LMWOAs in detoxification of some HMs was well recognised, participation of LMWOAs in changing the toxicity of $\mathrm{Cd}$ and $\mathrm{Cu}$ excess in plants is still poorly understood. Chaffai et al. (2006) suggested that the role of LMWOAs in $\mathrm{Cd}$ and $\mathrm{Cu}$ detoxification is based on the internal complexation and compartmentation in the vacuole rather than on extracellular mechanism. According to these authors, increasing accumulation of citrate and malate in maize plants growing in excess of $\mathrm{Cu}$ or $\mathrm{Cd}$ suggests importance of these acids in internal HMs detoxification. Yang et al. (2005) indicated that citrate has strong affinity for $\mathrm{Cd}$ and $\mathrm{Zn}$ in leaves. In turn, citrate is one of the principal ligands for $\mathrm{Cu}, \mathrm{Ni}$, and $\mathrm{Zn}$ in the xylem sap moving from the roots upwards into the leaves. Additional difficulty in recognizing the role of LMWOAs in excess of $\mathrm{Cu}$ and $\mathrm{Cd}$ is the distinct stress response depending on the plant cell age. It is commonly known that plant response to $\mathrm{Cd}$ and $\mathrm{Cu}$ depends on plant age (Maksymiec and Baszyński 1996a, b; Skórzyńska-Polit and Baszyński 1997; Krupa and Moniak 1998; Dresler and Maksymiec 2013). Previous studies on the age-dependent response of monocotyledon leaf segments to $\mathrm{Cd}$ stress showed that $\mathrm{Cd}$ reduced photochemical processes more efficiently in older than younger leaf sections (Drążkiewicz et al. 2003). Additionally, in Cd-exposed plants, various phytochelatin concentrations were discovered in relation to leaf segments and $\mathrm{Cd}$ concentration (Drążkiewicz et al.
2003; Drążkiewicz and Baszyński 2005). Dresler and Maksymiec (2013) observed various ascorbate (AA) and glutathione (GSH) concentrations related to the $\mathrm{Cd}$ or $\mathrm{Cu}$ plant treatment and section of maize leaf. According to these authors, $\mathrm{Cu}$ excess increased GSH and glutathione disulphide in all the leaf sections and AA in old and mature sections, while GSH increased in old leaf sections and decreased in young leaf sections in Cd-exposed plants. Furthermore, the concentration of AA in the Cd-treated plants was similar to the control.

In the present study, we investigate in a short time experiment the effects of acute stress caused by high $\mathrm{Cd}$ and $\mathrm{Cu}$ concentrations on maize plants and the response and LMWOA accumulation in roots and in different-aged segments of leaves. Moreover, the $\mathrm{Cd}$ and $\mathrm{Cu}$ effect on the growth, photosynthetic pigments, malondialdehyde (MDA) content, relative electrolyte leakage (REL) and the content of $\mathrm{Cu}$ and $\mathrm{Cd}$ in plant tissues are presented.

\section{Materials and methods}

\section{Plant material}

Seeds of maize (Zea mays L. cv. Reduta) were germinated for 2 days on wet filter paper in a thermostat-controlled chamber. Similar looking seedlings (about $1 \mathrm{~cm}$ long germ and 5-8 cm long roots) were transferred into Hoagland full strength nutrient solution. After adaptation for 2 days (4 days from germination), the nutrient solution was changed and the plants were treated with $\mathrm{Cd}(50,100 \mu \mathrm{M})$ or $\mathrm{Cu}(50,100 \mu \mathrm{M})$. Cadmium and $\mathrm{Cu}$ were added as $\mathrm{Cd}\left(\mathrm{NO}_{3}\right)_{2}$ and $\mathrm{CuSO}_{4}$ (Sigma), respectively. The control plants remained without $\mathrm{Cu}$ or $\mathrm{Cd}$ addition. The plants were grown for another 8 days at a day/night cycle of $16 / 8 \mathrm{~h}$ and $24 / 17^{\circ} \mathrm{C}$, respectively, relative humidity $60-70 \%$, and photosynthetic photon flux density of $150 \mu \mathrm{mol} \mathrm{m}{ }^{-2} \mathrm{~s}^{-1}$. The nutrient solution for control plants, as well as that containing $\mathrm{Cd}$ or excess $\mathrm{Cu}$, was changed after 4 days. After 8 days from metal treatment (12 days from germination), the plants were divided into shoots and roots, and the fresh mass of shoot and roots was weighed. The third leaf was sampled and cut into three sections of equal length from the basal (young) through the middle (mature) to the apical part (old) (Fig. 1). Furthermore, roots were collected after thorough washing with distilled water. The primary root net growth rates (NGR) during the 10 days of the $\mathrm{Cd}$ treatment were calculated as follows: (final length—initial length/initial length).

\section{Organic acid estimation}

Fresh plant tissue samples (aliquots of 50-200 mg part of leaf or root) were extracted by homogenisation in distilled water $(2 \mathrm{ml})$. The homogenate was incubated for $30 \mathrm{~min}$ at 


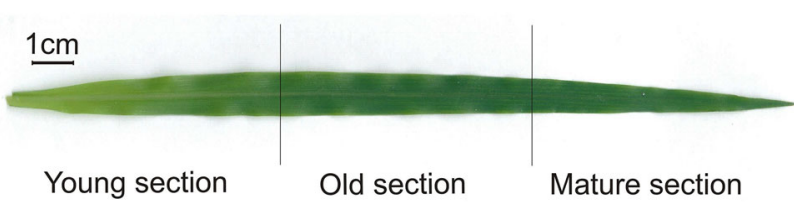

Fig. 1 Sections of the third leaf of Zea mays growing for 12 days

$50{ }^{\circ} \mathrm{C}$. After cooling, the mixture was centrifuged at $10,000 \times g$ for $5 \mathrm{~min}$. Finally, before sample injection into the CE system, the supernatant was filtered through $0.20 \mu \mathrm{m}$ nylon filters. Measurements were performed on an Agilent 7,000 capillary electrophoresis system (Agilent Technologies) equipped with a diode array spectrophotometric detector (190-600 nm). The capillary electrophoresis separation was performed according to the method described by Soga and Ross (1997). Briefly, a fused-silica capillary with $75 \mu \mathrm{m}$ id with effective lengths of $72 \mathrm{~cm}$ (80.5 cm total length) (Agilent Technologies) was used. The applied voltage was set at $-25 \mathrm{kV}$ (negative polarity mode). The samples were injected by pressure $(50 \mathrm{mbar})$ for $4.0 \mathrm{~s}$. Prior to first use, new capillaries were rinsed with run buffer under pressure (approximately with 1 bar) for $15 \mathrm{~min}$. Before each injection, the capillary was preconditioned for $4 \mathrm{~min}$ by flushing with the run electrolyte. Background electrolytes contained $5 \mathrm{mM}$ 2,6-pyridinedicarboxylic acid (PDC, Sigma) and $0.5 \mathrm{mM}$ cetyltrimethylammonium bromide (CTAB, Sigma), which were used to reverse the direction of electroosmotic flow. The $\mathrm{pH}$ was adjusted to 5.6 with $1 \mathrm{M} \mathrm{NaOH}$. The data obtained were analysed using ChemStation data analysis software (3D-CE ChemStation, Agilent Technologies).

\section{Lipid peroxidation assay}

For MDA determination, $0.5 \mathrm{~g}$ of each plant leaf section or roots was homogenised in $0.1 \%$ trichloroacetic acid (TCA) and centrifuged at $10,000 \times g$ for $10 \mathrm{~min} .0 .5 \%$ 2-thiobarbituric acid (TBA) in $20 \%$ TCA was added to the supernatant. The mixture was heated for $30 \mathrm{~min}$ at $95{ }^{\circ} \mathrm{C}$, quickly cooled, and centrifuged at $10,000 \times g$ for $10 \mathrm{~min}$. The absorbance of the supernatant was read at 532 and $600 \mathrm{~nm}$ (Tewari et al. 2002). The level of lipid peroxidation is defined as the MDA content.

Analysis of relative electrolyte leakage

Leaf disks of 6-mm diameter each $(0.2 \mathrm{~g})$ from fresh plants were washed for $3 \mathrm{~min}$ with ultrapure water $(40 \mathrm{ml})$ (MilliQ, Millipore, USA). Next, the leaf disks were dried with filter paper, placed in test tubes containing ultrapure water $(10 \mathrm{ml})$ and shaken for $3 \mathrm{~h}$ at $25{ }^{\circ} \mathrm{C}$ to measure initial conductivity (L1) (MPC227 meter, Mettler Toledo, Switzerland). Afterwards, the leaf disks were heated for 20 min at $95{ }^{\circ} \mathrm{C}$ to measure final conductivity (L2). REL was calculated as REL $(\%)=(\mathrm{L} 1 / \mathrm{L} 2) \times 100$.

Chlorophyll and carotenoid content

Chlorophyll $(a+b)$ and carotenoids were extracted in $80 \%$ acetone and calculated according to Wellburn (1994).

\section{Copper and cadmium content}

For copper and cadmium determination, the root (after rinsing, incubated in ice-cooled $10 \mathrm{mM} \mathrm{CaCl}_{2}$ solution for $30 \mathrm{~min}$ ) and sections of leaf samples were dried at $105^{\circ} \mathrm{C}$ to a constant dry weight. Afterwards, the dry material was wet digested in mixed acids $\left[\mathrm{HNO}_{3}+\mathrm{HClO}_{4}(4: 1, \mathrm{v} / \mathrm{v})\right.$, Sigma]. The cadmium and copper concentrations were measured by atomic absorption spectrophotometry.

Statistics analysis

Principal component analysis (PCA) of the LMWOA content and growth parameters of control and $\mathrm{Cd}-$ and $\mathrm{Cu}-$ treated plants was carried out. Using analysis of variance (two-way ANOVA), the effects of excess $\mathrm{Cu}$ or $\mathrm{Cd}$ on growth parameters, LMWOAs, MDA, REL, and photosynthetic pigments content in the leaf sections were analysed. Differences between the levels were determined with Fisher's least significance difference test at the 0.05 probability level. The data were analysed using Statistica ver. 6 (StatSoft, Inc. 2004).

\section{Results}

Growth parameters and content of photosynthetic pigments

In the present investigation, both $\mathrm{Cd}$ and $\mathrm{Cu}$ significantly reduced the fresh biomass. The 50 or $100 \mu \mathrm{M}$ cadmium concentration reduced the aboveground part weight approximately by 40 and $50 \%$ and the root weight by 34 and $57 \%$, respectively. Excess $\mathrm{Cu}$ reduced the weight of shoots by $\sim 70 \%$ and roots by $80 \%$ (both $\mathrm{Cu}$ concentration). After Cd treatment, NGR decreased by 15 and $40 \%(50$ and $100 \mu \mathrm{M}$, respectively) and $\mathrm{Cu}$ by $60 \%$ (Fig. 2).

The content of photosynthetic pigments (expressed as $\mathrm{mg} \mathrm{g}^{-1} \mathrm{FW}$ of leaf section) depended on the age of each section and the concentration of $\mathrm{Cd}$ or $\mathrm{Cu}$ in the nutrient solution (Fig. 3a, b). The control and heavy metal-treated maize plants accumulated the greatest amount of pigments 
Fig. 2 The effect of $\mathrm{Cd}$ and $\mathrm{Cu}$ on growth parameters of maize seedlings. Mean $( \pm$ SE) with the different letters within the same growth parameter are significantly different according to Fisher's test $(p<0.05)$ $(n=12)$

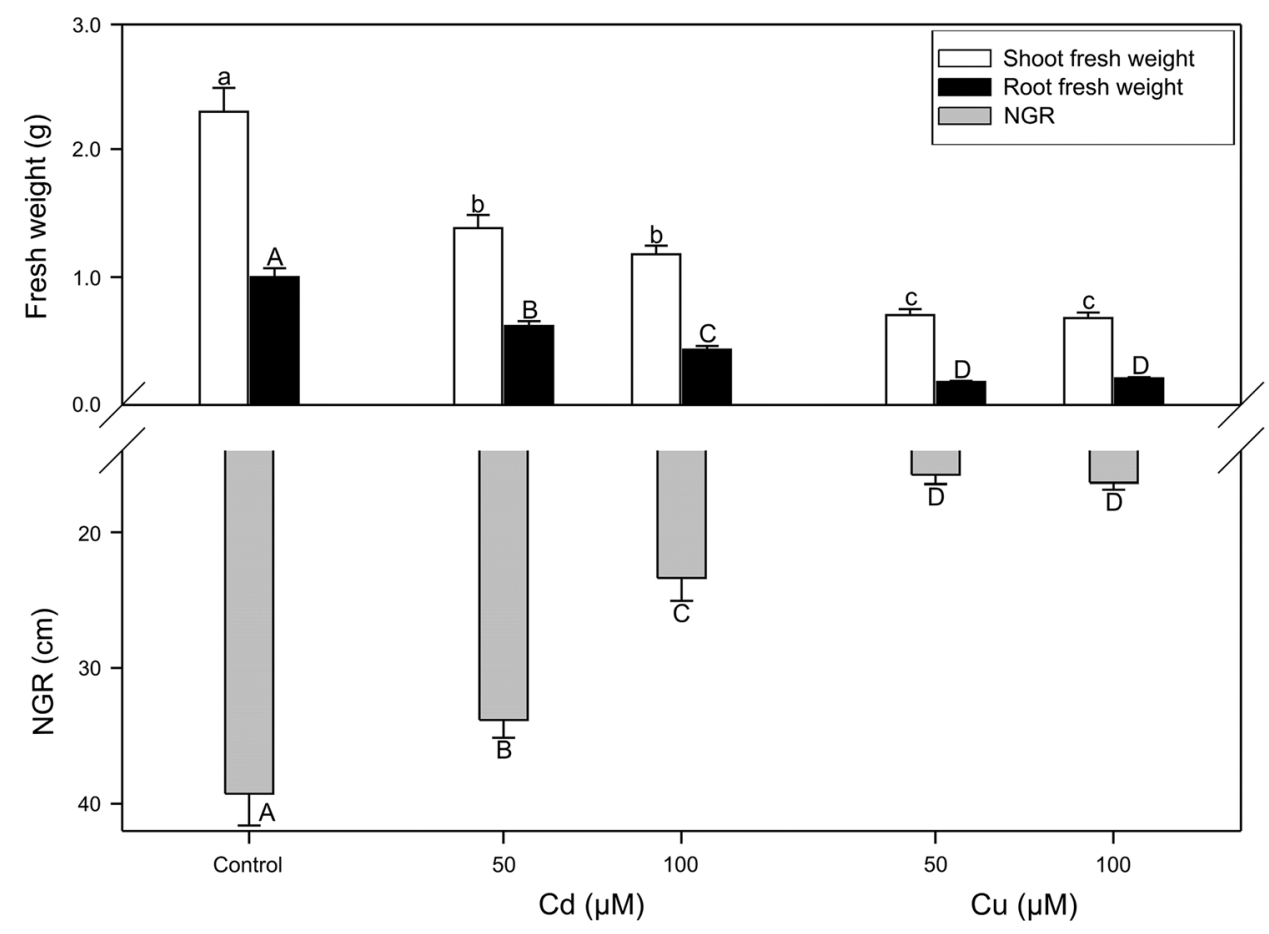

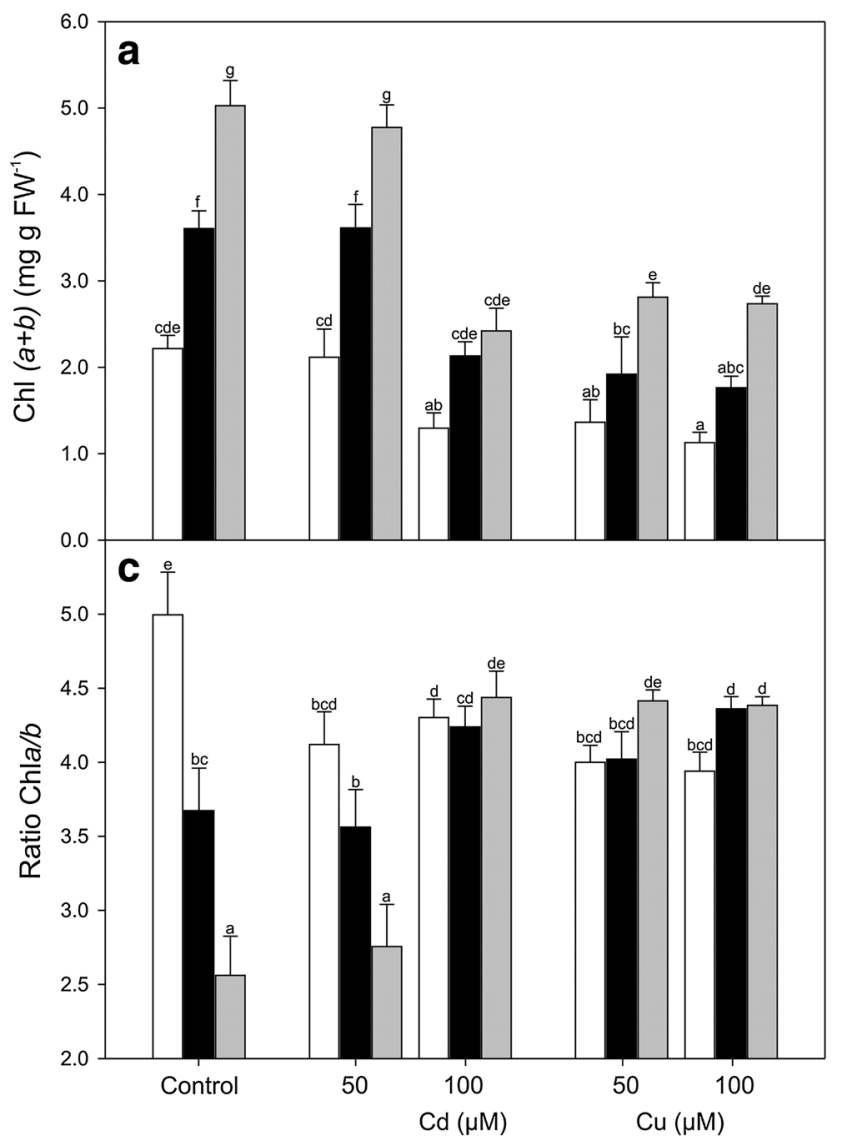

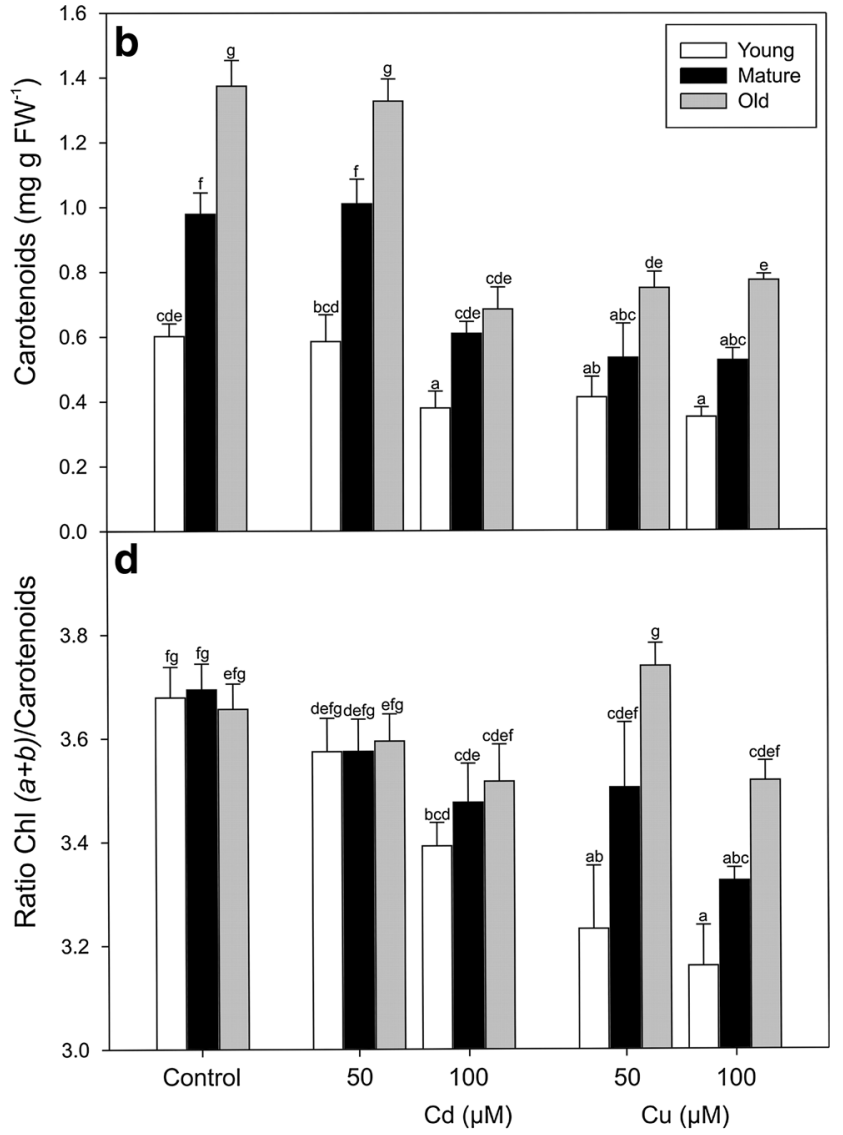

Fig. 3 Effect of $\mathrm{Cd}$ and $\mathrm{Cu}$ on the content of photosynthetic pigments in leaf sections differing in age of Zea mays seedlings. Mean $( \pm \mathrm{SE})$ with the different letters within the same parameter are significantly different according to Fisher's test $(p<0.05)(n=4)$ 
in the oldest leaf sections. However, after $50 \mu \mathrm{M}$ of $\mathrm{Cu}$ and $100 \mu \mathrm{M}$ of $\mathrm{Cu}$ or $\mathrm{Cd}$ treatments, the sum of chlorophyll and total carotenoid pools decreased mostly in mature and old leaf sections. The chlorophyll $a / b$ ratio in maize leaf sections ranged between 2.6 and 5.0 (Fig. 3c). However, Cd and $\mathrm{Cu}$ stress significantly decreased the $\mathrm{Chl} a / b$ ratio in young leaf segments and increased the value of the parameter in the 50 or $100 \mu \mathrm{M} \mathrm{Cu}$ or $100 \mu \mathrm{M} \mathrm{Cd}$ variant in the older sections. Figure $3 \mathrm{~d}$ illustrates the changes in the ratio of the sum of chlorophyll $(a+b)$ to total carotenoids that occurred in leaf segments in the $\mathrm{Cd}$ or $\mathrm{Cu}$ treatments. It was observed that the ratio of $\operatorname{Chl}(a+b) / \mathrm{Car}$ increased with increasing age of leaf segments exposed to $\mathrm{Cu}$, whilst
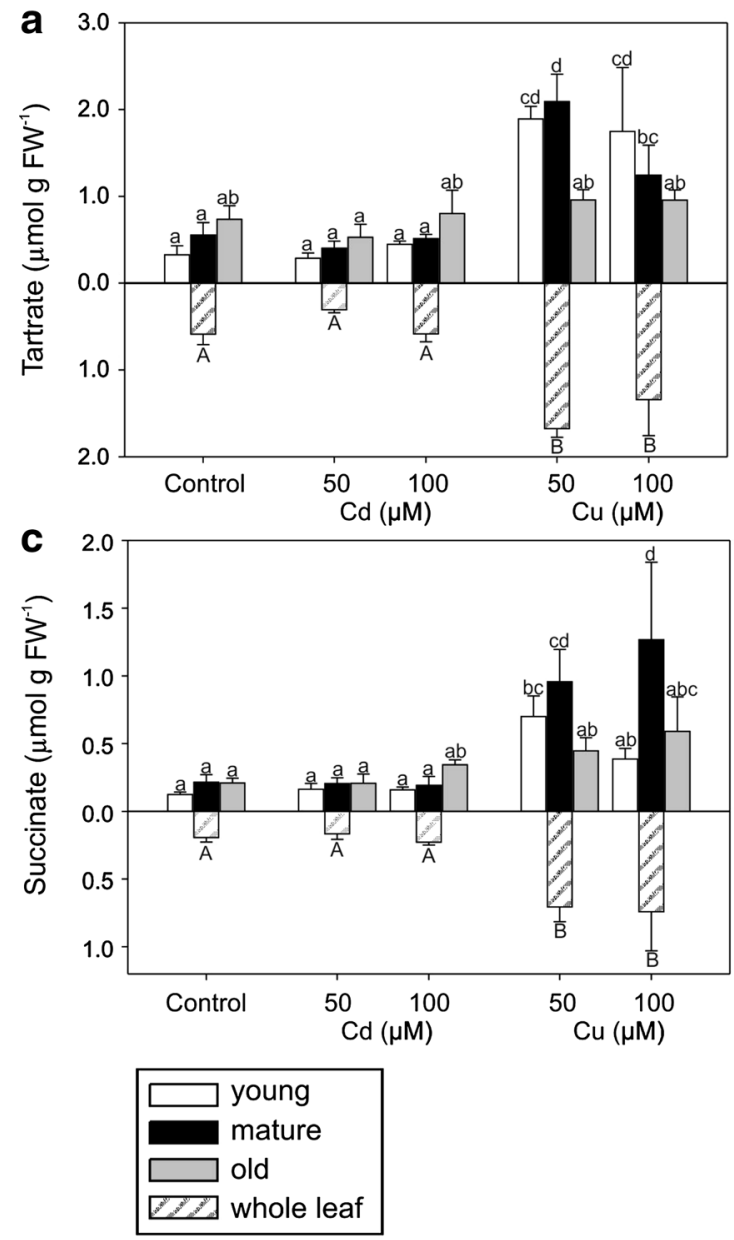

in the control and cadmium treatment the ratios of $\operatorname{Chl}(a+b) /$ Car were similar in all the leaf sections.

Organic acid accumulation

Five types of LMWOAs were identified in the leaf sections and four in the root extracts (the concentration of pyruvate in roots of maize was under the limit of detection) of Zea mays plants (Fig. 4; Table 1). Tartrate and succinate content in the shoots of the control and treated maize plants showed a similar tendency to accumulation (Fig. 4a, c). The concentration of these acids increased in the whole leaf of maize exposed to $\mathrm{Cu}$ in comparison with the control and
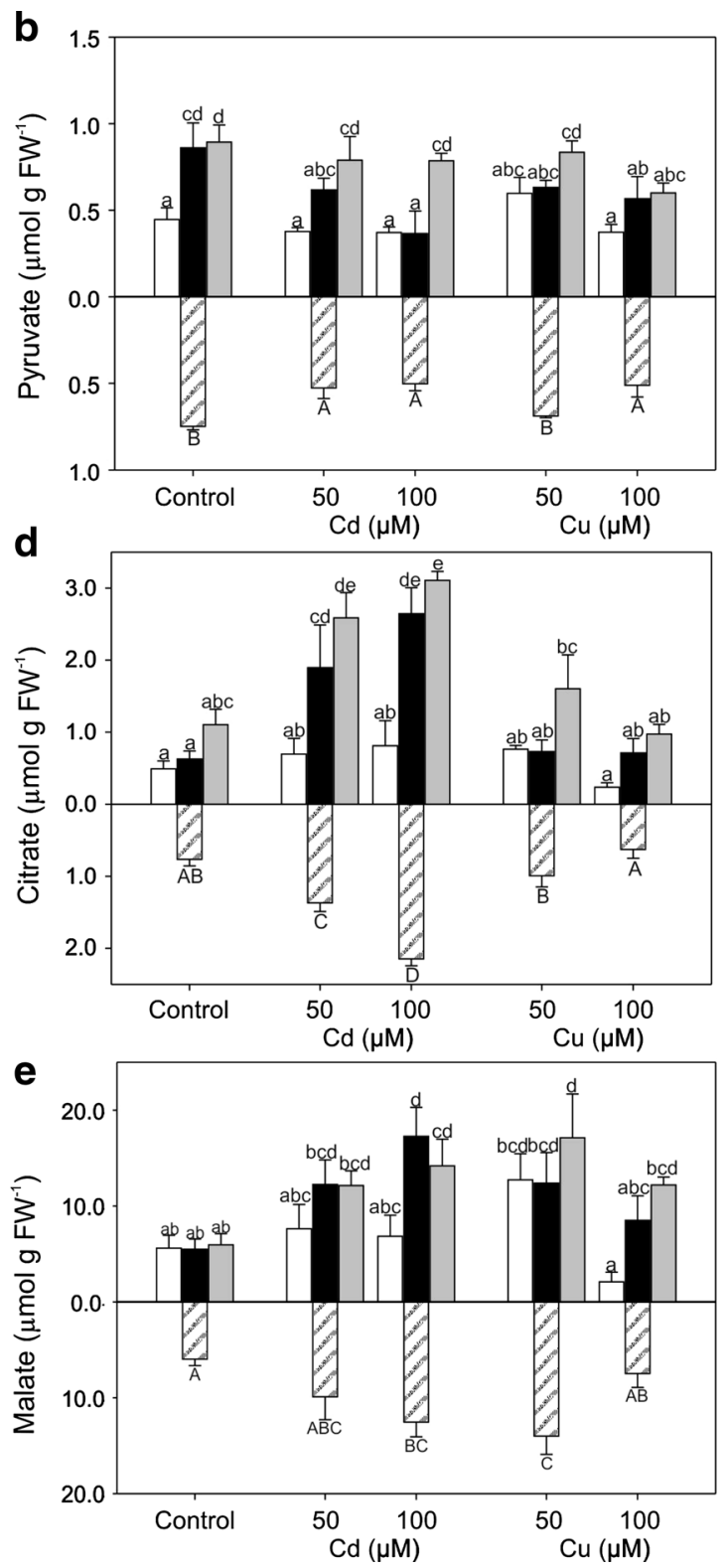

Fig. 4 Effect of $\mathrm{Cu}$ and $\mathrm{Cd}$ on LMWOAs concentration in Zea mays leaf segments. Mean $( \pm \mathrm{SE})$ with the different letters within the same parameter are significantly different according to Fisher's test $(p<0.05)(n=4)$ 
Table 1 Effect of $\mathrm{Cu}$ and $\mathrm{Cd}$ on organic acids $\left(\mu \mathrm{mol} \mathrm{g} \mathrm{f} \mathrm{wt}{ }^{-1}\right)(n=4)$ and MDA $(n=12)\left(\mathrm{nmol} \mathrm{g} \mathrm{f} \mathrm{wt}^{-1}\right)$ content in roots of Zea mays

\begin{tabular}{llllll}
\hline & Tartrate & Malate & Citrate & Succinate & MDA \\
\hline Control & $0.216 \pm 0.083 \mathrm{~b}$ & $0.392 \pm 0.088 \mathrm{a}$ & $0.069 \pm 0.029 \mathrm{a}$ & $0.049 \pm 0.032 \mathrm{a}$ & $2.23 \pm 0.055 \mathrm{a}$ \\
$\mathrm{Cd}$ & & & & & \\
$50 \mu \mathrm{M}$ & $1.075 \pm 0.177 \mathrm{a}$ & $1.606 \pm 0.360 \mathrm{bc}$ & $0.370 \pm 0.071 \mathrm{a}$ & $0.169 \pm 0.014 \mathrm{~b}$ & $3.15 \pm 0.408 \mathrm{ab}$ \\
$100 \mu \mathrm{M}$ & $0.786 \pm 0.114 \mathrm{a}$ & $0.851 \pm 0.080 \mathrm{ab}$ & $0.189 \pm 0.043 \mathrm{a}$ & $0.095 \pm 0.034 \mathrm{ab}$ & $3.27 \pm 0.448 \mathrm{ab}$ \\
$\mathrm{Cu}$ & & & & & \\
$50 \mu \mathrm{M}$ & $1.098 \pm 0.122 \mathrm{a}$ & $3.336 \pm 0.458 \mathrm{c}$ & $0.769 \pm 0.077 \mathrm{~b}$ & $0.141 \pm 0.029 \mathrm{ab}$ & $8.90 \pm 2.554 \mathrm{c}$ \\
$100 \mu \mathrm{M}$ & $0.640 \pm 0.239 \mathrm{ab}$ & $2.095 \pm 0.563 \mathrm{~d}$ & $0.837 \pm 0.334 \mathrm{~b}$ & $0.138 \pm 0.059 \mathrm{ab}$ & $6.23 \pm 0.893 \mathrm{bc}$ \\
\hline
\end{tabular}

The values are mean $\pm \mathrm{SE}$

Different letters denote significant differences between the treatments at $p<0.05$

Cd-treated plants. $\mathrm{Cu}$ excess increased succinate levels mainly in the mature sections of the leaves, whereas in the lowest $\mathrm{Cu}$ concentration increased the tartrate content about sixfold in young and fourfold in mature leaf segments compared to the control. In the oldest leaf sections, the concentration of that acid was not significantly different between the treatments. By contrast, the citrate level significantly increased in mature and old leaf sections in the Cd-exposed plants $(304,427 \%$-for mature, and 235, $282 \%$-for old, compared to the control at 50 or $100 \mu \mathrm{M}$, respectively) (Fig. 4d). Along with leaf ageing, the pyruvate concentration showed a tendency to increase; however, this effect was not significant in the tested plants (Fig. 4b). The main organic acid in the leaves of Zea mays plants was malate (Fig. 4e). However, its content exhibited several differences related to leaf cell age and the $\mathrm{Cu}$ or $\mathrm{Cd}$ treatment and accounted for approximately from 40 to $80 \%$ of the total acid content. Although $100 \mu \mathrm{M} \mathrm{Cu}$ or $50 \mu \mathrm{M} \mathrm{Cd}$ did not have a significant effect on the malate concentration in the leaf segments, a tendency for malate to increase in mature and old sections was noted. A similar significant effect was observed in the case of $100 \mu \mathrm{M} \mathrm{Cd}$ or $50 \mu \mathrm{M} \mathrm{Cu}$. Cadmium and $\mathrm{Cu}$ excess increased the malate concentration approximately threefold both in the mature leaf segments growing at $100 \mu \mathrm{M} \mathrm{Cd}$ and in the old leaf section at $50 \mu \mathrm{M} \mathrm{Cu}$ compared to the control.

As seen from Table 1, the content of organic acids in roots after the action of $\mathrm{Cd}$ or $\mathrm{Cu}$ had a tendency to increase. Fifty or $100 \mu \mathrm{M} \mathrm{Cd}$ and $50 \mu \mathrm{M} \mathrm{Cu}$ significantly elevated the tartrate concentration. In the case of malate, a similar increase was detected after application of $\mathrm{Cu}$ (both concentrations) or $50 \mu \mathrm{M} \mathrm{Cd}$. Although the citrate concentration in shoots did not increase after $\mathrm{Cu}$ action, in roots it reached 1,100 and 1,200\% of the control at 50 or $100 \mu \mathrm{M} \mathrm{Cu}$, respectively. In contrast to the shoot results, exposure to $\mathrm{Cd}$ had no significant effect on the citrate content in roots. The succinate content in roots showed a slight increase in response to $\mathrm{Cd}$ or $\mathrm{Cu}$; however, a significant increase was observed only in $50 \mu \mathrm{M} \mathrm{Cd}$.
The PCA of the organic acid concentrations and growth parameters in the plants studied (Fig. 5) showed clear separation between the control and plants treated with $\mathrm{Cd}$ and $\mathrm{Cu}$. The first two PCs explained $47.7 \%$ of the total variance. The first component (PC1-30.2\% of the variation) is largely negatively determined by shoot and root fresh weight. Additionally, the PC1 has strong positive loadings on the malate and citrate concentration in roots and tartrate and succinate in all the three leaf sections examined. The PC1 separated the $\mathrm{Cu}$ effect from the control and Cd-treated plants. On the other hand, the second component (PC2), which accounted for $17.5 \%$ of the variation, was mainly explained by the content of malate and citrate in leaves and tartrate in roots.

\section{Lipid peroxidation and relative electrolyte leakage level}

Our results showed that the level of lipid peroxidation of cell membranes increased with the age of leaf sections (Table 2). In the presence of $50 \mu \mathrm{M} \mathrm{Cd}, \mathrm{MDA}$ in the leaf sections increased significantly about 4-, 3- and 2.5fold in the young, mature, and old leaf sections, respectively. However, when the plants were exposed to $100 \mu \mathrm{M} \mathrm{Cd}$ or $\mathrm{Cu}$ (both 50 and $100 \mu \mathrm{M}$ concentrations), the levels of this parameter were similar to the control. The MDA levels in the roots of the Cd-treated plants were similar to the control, while 50 or $100 \mu \mathrm{M} \mathrm{Cu}$ increased the MDA level approximately 4- and 3-fold, respectively.

Table 3 shows the REL value in the leaf sections. The results obtained indicate that electrolyte leakage was increased in the young leaf sections in all the treatments as well as in the control.

\section{Copper and cadmium content}

The concentrations of $\mathrm{Cu}$ and $\mathrm{Cd}$ in leaf segments and roots are shown in Fig. 6. Both cations content showed an upward trend in the treated plants with the age of 
Fig. 5 Scatter plot of the PCA of LMWOAs concentrations in selected leaves sections and roots, and growth parameters variations in the Zea mays seedlings grown in control or exposed to $\mathrm{Cu}$ and $\mathrm{Cd}$. Length of lines of the scatter plot overlay shows correlation between original data and PC axes

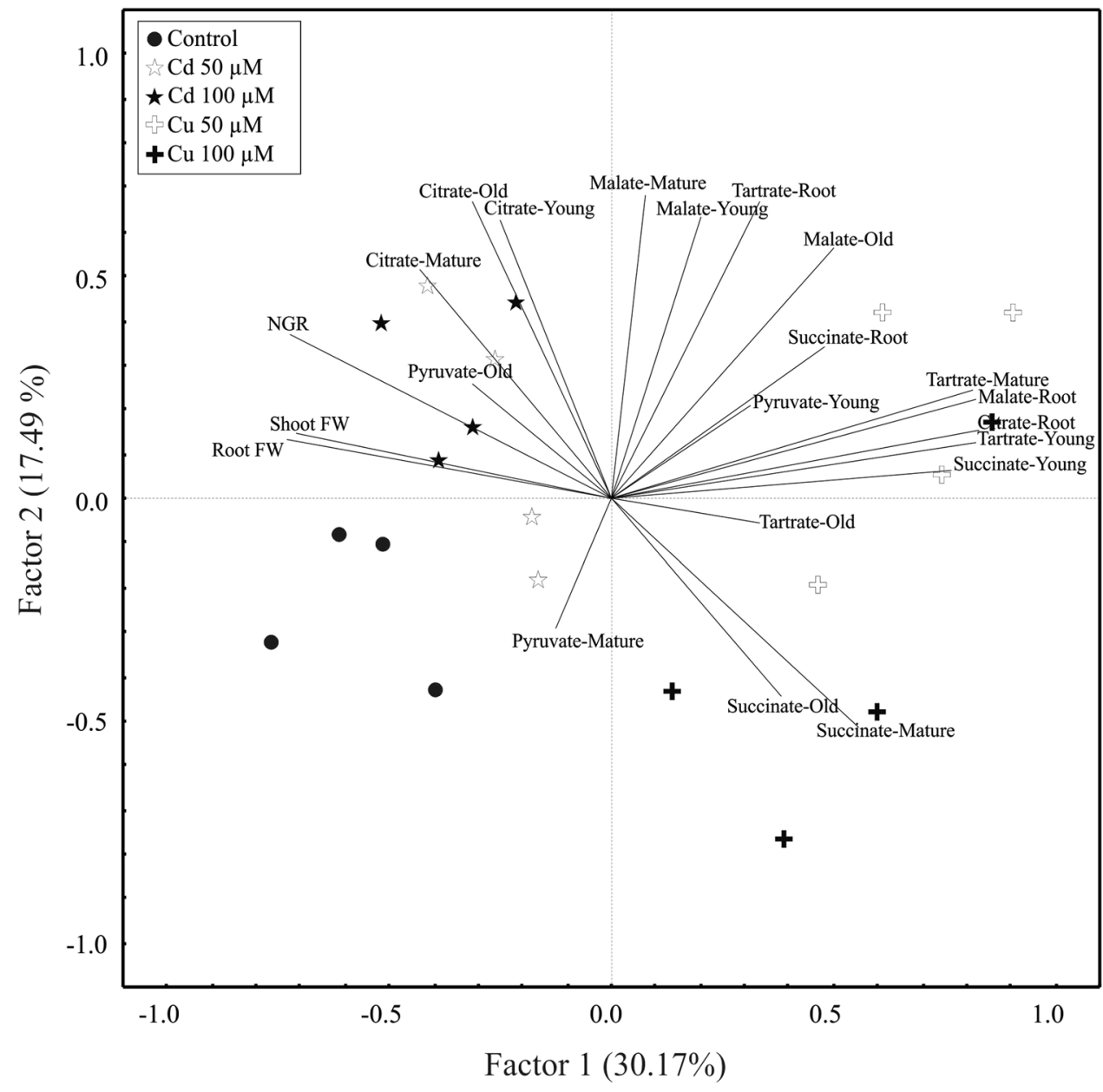

Table 2 MDA ( $\left.\mathrm{nmol} \mathrm{g} \mathrm{f} \mathrm{wt}^{-1}\right)$ content in leaf segments of Zea mays seedlings treated with $\mathrm{Cd}$ and $\mathrm{Cu}(n=12)$

\begin{tabular}{|c|c|c|c|c|c|}
\hline \multirow[t]{2}{*}{ Leaf segments } & \multirow[t]{2}{*}{ Control } & \multicolumn{2}{|l|}{$\mathrm{Cd}$} & \multicolumn{2}{|l|}{$\mathrm{Cu}$} \\
\hline & & $50 \mu \mathrm{M}$ & $100 \mu \mathrm{M}$ & $50 \mu \mathrm{M}$ & $100 \mu \mathrm{M}$ \\
\hline Young & $27.31 \pm 6.14 \mathrm{ab}$ & $107.16 \pm 4.18 \mathrm{e}$ & $31.89 \pm 6.06 \mathrm{ab}$ & $16.16 \pm 2.93 \mathrm{a}$ & $37.88 \pm 12.12 \mathrm{ab}$ \\
\hline Mature & $51.60 \pm 9.66 \mathrm{bcd}$ & $159.22 \pm 1.98 \mathrm{f}$ & $53.31 \pm 11.58 \mathrm{bcd}$ & $37.62 \pm 2.63 \mathrm{ab}$ & $42.86 \pm 14.29 \mathrm{abc}$ \\
\hline Old & $67.93 \pm 7.86 \mathrm{~cd}$ & $162.24 \pm 11.64 \mathrm{f}$ & $76.36 \pm 12.31 \mathrm{~d}$ & $51.56 \pm 19.71 \mathrm{bcd}$ & $53.42 \pm 9.86 \mathrm{bcd}$ \\
\hline
\end{tabular}

The values are mean $\pm \mathrm{SE}$

Different letters denote significant differences between the treatments at $p<0.05$

Table 3 REL value in leaf segments of Zea mays seedlings treated with $\mathrm{Cd}$ and $\mathrm{Cu}(n=12)$

\begin{tabular}{|c|c|c|c|c|c|}
\hline \multirow[t]{2}{*}{ Leaf segments } & \multirow[t]{2}{*}{ Control } & \multicolumn{2}{|l|}{$\mathrm{Cd}$} & \multicolumn{2}{|l|}{$\mathrm{Cu}$} \\
\hline & & $50 \mu \mathrm{M}$ & $100 \mu \mathrm{M}$ & $50 \mu \mathrm{M}$ & $100 \mu \mathrm{M}$ \\
\hline Young & $17.22 \pm 1.27 \mathrm{c}$ & $12.10 \pm 1.12 \mathrm{a}$ & $12.86 \pm 0.99 \mathrm{ab}$ & $15.72 \pm 1.61 b c$ & $13.03 \pm 0.66 \mathrm{ab}$ \\
\hline Mature & $12.53 \pm 0.88 \mathrm{ab}$ & $10.82 \pm 0.92 \mathrm{a}$ & $11.21 \pm 1.04 \mathrm{a}$ & $13.05 \pm 1.23 \mathrm{ab}$ & $12.59 \pm 0.96 \mathrm{ab}$ \\
\hline Old & $10.51 \pm 1.15 \mathrm{a}$ & $11.18 \pm 1.84 \mathrm{a}$ & $9.51 \pm 0.84 \mathrm{a}$ & $12.09 \pm 0.98 \mathrm{ab}$ & $12.93 \pm 3.15 \mathrm{ab}$ \\
\hline
\end{tabular}

The values are mean \pm SE

Different letters denote significant differences between the treatments at $p<0.05$ 
Fig. 6 The mean of the $\mathrm{Cu}$ (a) and $\mathrm{Cd}$ (b) content in $\mathrm{Zea}$ mays leaf segments and roots grown under copper or cadmium treatment for 8 days. Mean $( \pm \mathrm{SE})$ with the different letters are significantly different according to Fisher's test $(p<0.05)(n=3)$
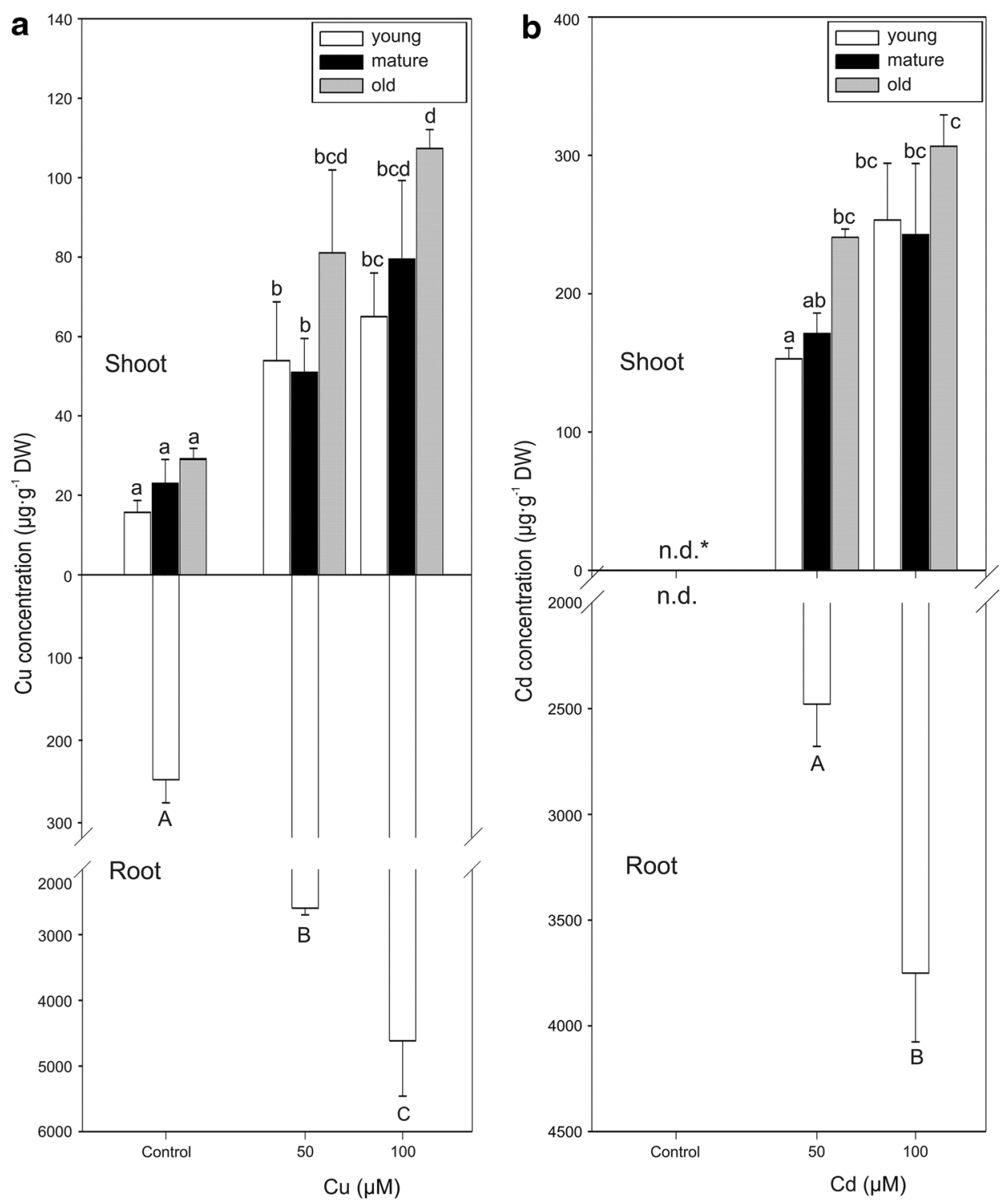

segments. The level of both metals in the leaf sections did not change significantly depending on the metal concentration in the nutrient medium. But, a significant increase was observed in the oldest sections after $100 \mu \mathrm{M} \mathrm{Cu}$ or $50 \mu \mathrm{M} \mathrm{Cd}$ treatments. The content of $\mathrm{Cu}$ and $\mathrm{Cd}$ in roots increased significantly with the increase in the concentration of the metals in the growth medium.

\section{Discussion}

LMWOAs play an important role in several biochemical pathways, including respiration and energy generation, aminoacid biosynthesis, photosynthesis, cation transport, and reduction of HM stress (Cataldo et al. 1988; López-Bucio et al. 2000; Schulze et al. 2002). The hypothesis about the participation of LMWOAs in detoxification of HMs was proposed by
Rauser (1999) based on previous study on accumulation of LMWOAs in plant tissues of various HM-tolerant plant clones. There is substantial evidence indicating a close relationship between the LMWOA content and tolerance to HMs (Thurman and Rankin 1982; Rauser 1999; Ma 2000; Boominathan and Doran 2003). However, the role of LMWOAs in detoxification of HMs is still being discussed (Hall 2002; Wójcik 2009).

The accumulation of LMWOAs in $\mathrm{Cu}$ - and $\mathrm{Cd}$-stressed plant tissues has been previously described by a few authors (Krotz et al. 1989; Chaffai et al. 2006; Wójcik et al. 2006); however, to our knowledge, the $\mathrm{Cu}$ and $\mathrm{Cd}$ influence on the concentration of LMWOAs in different leaf developmental stages has not been investigated.

In the present study, the strong $\mathrm{Cu}$ and $\mathrm{Cd}$ effect on LMWOA accumulation in leaves and roots was observed. The results obtained indicated that excess $\mathrm{Cu}$ increased tartrate, succinate, and malate levels, while $\mathrm{Cd}$ had a 
positive effect on citrate and malate in leaves. Similar results have been previously reported by Chaffai et al. (2006). According to these authors, in response to $\mathrm{Cd}$ and $\mathrm{Cu}$ stress, maize roots accumulate more citrate, while leaves accumulate malate at $\mathrm{Cu}$ excess and citrate at $\mathrm{Cd}$ treatment.

Moreover, our results indicate that $\mathrm{Cd}$ (both 50 and $100 \mu \mathrm{M})$ had a positive influence on the citrate concentration only in the mature and old leaf sections. The result implies that citrate and malate (at high $\mathrm{Cd}$ concentrations) probably play a role in $\mathrm{Cd}$ transport and sequestration in old leaves while malate participates in $\mathrm{Cu}(50 \mu \mathrm{M} \mathrm{Cu}$ concentration) detoxification in old leaf sections. This conclusion reinforces the hypothesis that citric acid is one of the Cd ligands and participates in Cd transport in xylem sap to the oldest part of plants (Cataldo et al. 1988, reviewed Clemens 2001). Previously (Krupa and Moniak 1998; Drążkiewicz et al. 2003), the lowest level of Cd was noted in young leaf sections of monocotyledonous plants, while mature and old sections retained the HM concentration at a high level. The afore-mentioned studies are in accordance with our results, however, only in $100 \mu \mathrm{M} \mathrm{Cu}$ and $50 \mu \mathrm{M}$ Cd treatments, where significantly different $\mathrm{Cu}$ or $\mathrm{Cd}$ concentrations between young and old sections were observed. The changes in $\mathrm{Cu}$ and $\mathrm{Cd}$ concentrations are similar to the values reported by Drążkiewicz et al. (2003) and Žaltauskaite and Šliumpaitè (2013). Higher $\mathrm{Cu}$ and $\mathrm{Cd}$ concentrations in roots than in shoots are commonly known in the literature (Tukendorf and Baszyński 1985; Chaffai et al. 2006). Drążkiewicz et al. (2003) indicated that lower $\mathrm{Cd}$ shoot concentrations could result from compartmentation of the metal with sulphur ligands in roots cells and restricted their transport into the above-ground parts of seedlings. Additionally, the higher concentration of LMWOAs obtained in metal-treated roots indicated possibilities of compartmentation of HMs by LMWOAs in roots.

Although there is some evidence that citrate participates in Cd complexation, comparison of the molar concentration of both acids (malate and citrate) in the leaves indicated that the content of the former acid was approximately tenfold greater than that of the latter. This observation shows that among LMWOAs malate plays a crucial role in detoxification of $\mathrm{Cd}$ and $\mathrm{Cu}$. However, the malate level increased significantly only after $100 \mu \mathrm{M}$ of $\mathrm{Cd}$ (mature and old sections) or $50 \mu \mathrm{M}$ of $\mathrm{Cu}$ (old sections), which may indicate that the lower concentration of $\mathrm{Cd}$ was not sufficiently toxic to induce malate synthesis while the strong toxic effect of $\mathrm{Cu}(100 \mu \mathrm{M})$ disturbed accumulation of malate. Wójcik et al. (2006) reported that malate was a predominant LMWOA in shoots and roots of T. caerulescens. Moreover, $\mathrm{Cd}$ and $\mathrm{Zn}$ stimulated malate accumulation in shoots while citrate was found only in $\mathrm{Zn}$-treated shoots.
Since the concentration of pyruvate in $\mathrm{Cu}$ - or $\mathrm{Cd}$ exposed maize leaves was similar to that in the control, determination of its role in HM tolerance was difficult. Interestingly, only $\mathrm{Cu}$ increased accumulation of succinate and tartrate in younger parts of leaves. This evidence could point out that those acids participate in $\mathrm{Cu}$ detoxification. The results of the study by Doncheva et al. (2006) demonstrated that exogenous succinate decreased the toxic effect of $\mathrm{Cu}$ on maize growth, photosynthesis pigment content, and activities of antioxidant enzymes. Furthermore, the authors confirmed the high affinity of succinate to $\mathrm{Cu}$. However, the higher concentration of these LMWOAs (succinate and tartrate) in the younger leaf sections under $\mathrm{Cu}$ stress indicates a different mechanism of $\mathrm{Cu}$ detoxification by malate and/ or $\mathrm{Cd}$ detoxification by citrate. The probable clue could be the limitation of translocation to the older leaf section. Nevertheless, one cannot exclude the possibility that the succinate and tartrate rise in $\mathrm{Cu}$-treated leaves was the result of a negative effect on the physiological process. We have shown that the growth of shoot and roots was more limited by $\mathrm{Cu}$ than by $\mathrm{Cd}$. Additionally, photosynthetic pigments that are considered as markers of plant physiological state were significantly decreased in $\mathrm{Cu}$ (both $\mathrm{Cu}$ concentrations) compared to the control and $50 \mu \mathrm{M}$ Cd-treated plants. Thus, the high toxicity effect of $\mathrm{Cu}$ could disturb the physiological pathways in which LMWOAs participate; therefore, the concentration of some of them was increased in the young leaf sections.

The age-dependent differences observed in the concentration of LMWOAs in $\mathrm{Cu}$ - and Cd-treated leaves were accompanied by definite changes in the Chla/b and $\mathrm{Chl}(a+b) /$ Carot ratios, compared to the control. The increase in the Chla/b ratio in young and mature $\mathrm{Cu}$-treated leaves $(50$ or $100 \mu \mathrm{M} \mathrm{Cu})$ or Cd-treated leaves $(100 \mu \mathrm{M})$ points out that those metals disturbed the antennae pigments, which are related to greater sensitivity of Chla than Chlb to HMs (Drążkiewicz and Baszyński 2005). It is known that HMs interfere with iron metabolism causing both iron deficiency and a decrease in chlorophyll synthesis, which was observed after $100 \mu \mathrm{M} \mathrm{Cd}, 50$ or $100 \mu \mathrm{M} \mathrm{Cu}$ supplementation. Additionally, the level of carotenoids decreased in the treatments mentioned above and they were not able to protect plants against 50 or $100 \mu \mathrm{M} \mathrm{Cu}$ or $100 \mu \mathrm{M} \mathrm{Cd}$.

Our results indicated that the $\mathrm{Cu}$ in excess exerted a more toxic effect than $\mathrm{Cd}$ on plant growth, which is in accordance with previous studies (Chaffai et al. 2006; Žaltauskaitè and Šliumpaite 2013); in contrast, Metwali et al. (2013) and Gupta and Abdullah (2011) did not observe such toxic effects of $\mathrm{Cu}$. Surprisingly, REL was not increased in the leaf segments in $\mathrm{Cd}$ or $\mathrm{Cu}$ excess, 
while MDA increased only in the roots of the $\mathrm{Cu}$-treated plants and in the leaves of $50 \mu \mathrm{M}$ Cd-treated maize. The increased MDA level could be connected with both increased $\mathrm{H}_{2} \mathrm{O}_{2}$ concentration and $\mathrm{Fe}$ efficiency. In some experiments, the induction of MDA, an oxidative marker, is more pronounced in roots than in leaves after metal stress, for example in $\mathrm{Cu}$-stressed rice seedlings (Mostofa and Fujita 2013). In the case of Cd stress, the increase in the MDA content was similar in leaves and roots (Cao et al. 2013). In our study, the level of stress monitored by the MDA level was more pronounced in senescent Zea mays leaves and more visible in the leaves after $\mathrm{Cd}$ treatment and in the roots after $\mathrm{Cu}$ application.

Furthermore, the MDA concentration was higher at the lower $\mathrm{Cd}$ dose. Hydroperoxides formed from lipids may have been preferentially converted at the higher $\mathrm{Cd}$ concentration into more stable compounds, including jasmonic acid, as was supposed by Rucinska and Gwózdz (2005) and supported by the findings of Maksymiec et al. (2005), which indicated rapid accumulation of jasmonic acid after heavy metal stress. The lack of significant changes in the membrane permeability additionally confirms this conclusion. After application of $50 \mu \mathrm{M} \mathrm{Cd}$, an especially high MDA level was detected, and no changes in membrane permeability were observed. Our results indicate that lipid peroxidation cannot destabilise cell membrane and are in accordance with results presented by $\mathrm{Li}$ et al. (2012), but those results depended on different factors, e.g. time of treatments and plant age.

As mentioned above, the different effect of both metals on accumulation of LMWOAs as well as photosynthetic pigments, MDA, and growth parameters is dependent on the different toxicity effects of $\mathrm{Cu}$ and $\mathrm{Cd}$. The excess of $\mathrm{Cu}$ induces oxidative damage by producing toxic free radicals; furthermore, $\mathrm{Cu}$ inhibits some of the enzymes implied in photosynthesis, whereas $\mathrm{Cd}$ has an ability to produce oxidative stress, but in contrast to $\mathrm{Cu}$, it does not participate directly in the production of reactive oxygen species via the Fenton reaction.

In conclusion, we showed that (1) both metals influenced differently the accumulation of LMWOAs in roots and in individual sections of maize leaf, (2) increasing accumulation of malate under metal stress in mature and old leaf sections might indicate that it plays a crucial role in $\mathrm{Cd}$ (higher concentration) and $\mathrm{Cu}$ (lower concentration) detoxification, (3) the increasing citrate concentration in old and mature leaf sections after $\mathrm{Cd}$ exposure implies specific participation of the acid in Cd detoxification, (4) only $\mathrm{Cu}$-exposed plants had an increased level of succinate and tartrate in the young leaf sections, (5) the $\mathrm{Cu}$ excess exerted a more toxic effect than $\mathrm{Cd}$ on plant growth and the content of photosynthetic pigments in maize seedlings.
Author contribution Study conception and design: Sławomir Dresler, Waldemar Maksymiec. Acquisition of data: Sławomir Drelsler, Agnieszka Hanaka, Wiesław Bednarek. Analysis and interpretation of data: Sławomir Dresler. Drafting of manuscript: Sławomir Dresler. Critical revision: Waldemar Maksymiec.

Acknowledgments Special thanks for technical support and help with the experiments are extended to Małgorzata Palusińska.

Open Access This article is distributed under the terms of the Creative Commons Attribution License which permits any use, distribution, and reproduction in any medium, provided the original author(s) and the source are credited.

\section{References}

Boominathan R, Doran PM (2003) Organic acid complexation, heavy metal distribution and the effect of ATPase inhibition in hairy roots of hyperaccumulator plant species. J Biotech 101:131-146

Burzyński M, Migocka M, Kłobus G (2005) Cu and Cd transport in cucumber (Cucumis sativus L.) root plasma membranes. Plant Sci 168:1609-1614

Cao F, Wang N, Zhang M, Dai H, Dawood M, Zhang G, Wu F (2013) Comparative study of allevating effects of GSH, Se and $\mathrm{Zn}$ under combination of cadmium and chromium in rice (Oryza sativa). Biometals 26:297-308

Cataldo DA, McFadden KM, Garland TR, Wildung RE (1988) Organic constituents and complexation of nickel(II), iron(III), cadmium(II), and plutonium(IV) in soybean xylem exudates. Plant Physiol 86:734-739

Chaffai R, Tekitek A, El Ferjani E (2006) A comparative study on the organic acid content and exudation in maize (Zea mays L.) seedlings under conditions of copper and cadmium stress. Asian J Plant Sci 5:598-606

Clemens S (2001) Molecular mechanisms of plant metal tolerance and homeostasis. Planta 212:475-486

Doncheva S, Stoyanova Z, Georgieva K, Nedeva D, Dikova R, Zehirov G, Nikolova A (2006) Exogenous succinate increases resistance of maize plants to copper stress. J Plant Nutr Soil Sci 169:247-254

Drążkiewicz M, Baszyński T (2005) Growth parameters and photosynthetic pigments in leaf segments of Zea mays exposed to cadmium, as related to protection mechanisms. J Plant Physiol 162:1013-1021

Drążkiewicz M, Tukendorf A, Baszyński T (2003) Age-dependent response of maize leaf segments to cadmium treatment: effect on chlorophyll fluorescence and phytochelatin accumulation. J Plant Physiol 160:247-254

Dresler S, Maksymiec W (2013) Capillary zone electrophoresis for determination of reduced and oxidized ascorbate and glutathione in roots and leaf segments of Zea mays plants exposed to $\mathrm{Cd}$ and $\mathrm{Cu}$. Acta Sci Pol Hortorum Cultus 12:143-155

Gupta D, Abdullah (2011) Toxicity of copper and cadmium on germination and seedling growth of maize (Zea mays L.) seeds. Indian J Sci Res 2:67-70

Hall JL (2002) Cellular mechanisms for heavy metal detoxification and tolerance. J Exp Bot 366:1-11

Harmens H, Koevoets PM, Verkleij JAC, Ernst WHO (1994) The role of low molecular weight organic acids in the mechanism of increased zinc tolerance in Silene vulgaris (Moench) Garcke. New Phytol 126:615-621 
Krotz RM, Evangelou BP, Wagner GJ (1989) Relationships between cadmium, zinc, Cd-peptide, and organic acid in tobacco suspension cells. Plant Physiol 91:780-787

Krupa Z, Moniak M (1998) The stage of leaf maturity implicates the response of the photosynthetic apparatus to cadmium toxicity. Plant Sci 138:149-156

Lee J, Reeves RD, Brooks RR, Jaffré T (1978) The relation between nickel and citric acid in some nickel-accumulating plants. Phytochemistry 17:1033-1035

Li X, Zhao M, Guo L, Huang L (2012) Effect of cadmium on photosynthetic pigments, lipid peroxidation, antioxidants, and artemisinin in hydroponically grown Artemisia aпnиа. J Environ Sci 24:1511-1518

López-Bucio J, Nieto-Jacobo MF, Ramírez-Rodríguez V, HerreraEstrella L (2000) Organic acid metabolism in plants: from adaptive physiology to transgenic varieties for cultivation in extreme soils. Plant Sci 160:1-13

Ma JF (2000) Role of organic acids in detoxification of aluminium in higher plants. Plant Cell Physiol 41(4):383-390

Maksymiec W, Baszyński T (1996a) Chlorophyll fluorescence in primary leaves of excess $\mathrm{Cu}$-treated runner bean plants depends on their growth stages and the duration of $\mathrm{Cu}$-action. J Plant Physiol 149:196-200

Maksymiec W, Baszyński T (1996b) Different susceptibility of runner bean plants to excess copper as a function of the growth stages of primary leaves. J Plant Physiol 149:217-221

Maksymiec W, Wianowska D, Dawidowicz AL, Radkiewicz S, Mardarowicz M, Krupa Z (2005) The level of jasmonic acid in Arabidopsis thaliana and Phaseolus coccineus plants under heavy metal stress. J Plant Physiol 162:1338-1346

Metwali EMR, Gowayed SMH, Al-Maghrabi OA, Mosleh YY (2013) Evaluation of toxic effect of copper and cadmium on growth, physiological traits and protein profile of wheat (Triticum aestivium L.), maize (Zea mays L.) and shorghum (Sorghum bicolor L.). World Appl Sci J 21:301-314

Mostofa MG, Fujita M (2013) Salicylic acid alleviates copper toxicity in rice (Oryza sativa L.) seedlings by up-regulating antioxidative and glyoxalase systems. Ecotoxicol 22:959-973

Rauser WE (1999) Structure and function of metal chelators produced by plants. Cell Biochem Biophys 31:19-48

Rucińska R, Gwóźdź EA (2005) Influence of lead on membrane permeability and lipoxygenase activity in lupine roots. Biol Plant 49:617-619

Ryan PR, Delhaize E, Jones DL (2001) Function and mechanism of organic anion exudation from plant roots. Annu Rev Plant Physiol Plant Mol Biol 52:527-560
Sanitá di Toppi L, Gabbrielli R (1999) Response to cadmium in higher plants. Environ Exp Bot 41:105-130

Schulze J, Tesfaye M, Litjens RHMG et al (2002) Malate plays a central role in plant nutrition. Plant Soil 247:133-139

Skórzyńska-Polit E, Baszyński T (1997) Differences in sensitivity of the photosynthetic apparatus in Cd-stressed runner bean plants in relation to their age. Plant Sci 128:11-21

Soga T, Ross GA (1997) Capillary electrophoretic determination of inorganic and organic anions using 2,6-pyridinedicarboxylic acid: effect of electrolyte's complexing ability. J Chromatography A 767:223-230

Tewari RK, Kumar P, Sharma PN, Bisht SS (2002) Modulation of oxidative stress responsive enzymes by excess cobalt. Plant Sci 162:381-388

Thurman DA, Rankin JL (1982) The role of organic acids in zinc tolerance in Deschampsia caespitose. New Phytol 91:629-635

Tukendorf A, Baszyński T (1985) Partial purification and characterization of copper-binding protein from roots of Avena sativa grown on excess copper. J Plant Physiol 120:57-63

Wellburn AR (1994) The spectral determination of chlorophylls $a$ and $b$, as well as total carotenoids, using various solvents with spectrophotometers of different resolution. J Plant Physiol 144:307-313

Wójcik M (2009) Vacuole as a multifunctional compartment in plant responses to stress factors. In: Maksymiec W (ed) Compartmentation of responses to stresses in higher plants, true or false. Transworld Reaserch Network, Kerala, pp 91-123

Wójcik M, Skórzyńska-Polit E, Tukiendorf A (2006) Organic acids accumulation and antioxidant enzyme activities in Thlaspi caerulescens under $\mathrm{Zn}$ and $\mathrm{Cd}$ stress. Plant Growth Regul 48:145-155

Yang XE, Baligar VC, Foster JC, Martens DC (1997) Accumulation and transport of nickel in relation to organic acids in ryegrass and maize grown with different nickel levels. Plant Soil 196:271-276

Yang XE, Jin XF, Feng Y, Islam E (2005) Molecular mechanisms and genetic basis of heavy metal tolerance/hyperaccumulation in plants. J Integr Plant Biol 45:1025-1035

Žaltauskaitė J, Šliumpaite I (2013) Evalutation of toxic effects and bioaccumulation of cadmium and copper in spring barley (Hordeum vulgare L.). Environ Res Eng Manage 64:51-58 